\title{
Long-term effect of different soil management systems and winter crops on soil acidity and vertical distribution of nutrients in a Brazilian Oxisol
}

\author{
Ademir Calegari ${ }^{\mathrm{a}}$, Tales Tiecher ${ }^{\mathrm{b}}$, William L. Hargrove ${ }^{\mathrm{c}}$, Ricardo Ralisch ${ }^{\mathrm{d}}$, Daniel Tessier ${ }^{\mathrm{e}}$, \\ Stéphane de Tourdonnet ${ }^{\mathrm{f}}$, Maria de Fátima Guimarães ${ }^{\mathrm{d}}$, Danilo Rheinheimer dos Santos ${ }^{\mathrm{b}, *}$ \\ a Soil Area, Instituto Agronômico do Paraná (IAPAR), Londrina, Paraná State, Brazil \\ ' Soil Department, Universidade Federal de Santa Maria (UFSM), 97105-900 Santa Maria, Rio Grande do Sul State, Brazil \\ ${ }^{\mathrm{c}}$ KCARE, K-State Research and Extension, Kansas State University, Manhattan, KS, USA \\ ${ }^{\mathrm{d}}$ Universidade Estadual de Londrina (UEL), Agronomy Department, Londrina, Paraná State, Brazil \\ ${ }^{\mathrm{e}}$ Institut National de la Recherche Agronomique (INRA), Versailles Cedex, France \\ ${ }^{\mathrm{f}}$ AgroParisTech, Département SAFEE, UMR d'Agronomie INRA/AgroParisTech Bâtiment, Thiverval-Grignon, France
}

\section{A R T I C L E I N F O}

\section{Article history:}

Received 31 October 2012

Received in revised form 18 May 2013

Accepted 23 May 2013

\section{Keywords:}

No-tillage

Conventional tillage

Winter cover crops

Nutrient availability

Subsurface soil fertility

\begin{abstract}
A B S T R A C T
"Strategies" to sustain crop productivity by reducing the fertilizer and lime demands must be developed. The use of plant species that use more efficiently the soil nutrients and tillage systems that provide nutrients accumulation in more labile forms are prerequisites for sustainable agroecosystems. This study aimed to evaluate the long period effect of cultivating different winter species under different soil management systems on vertical distribution of soil nutrients and the soil acidity distribution in soil profile. The experiment was established in 1986 with six winter treatments (blue lupine, hairy vetch, oat, radish, wheat and fallow) under conventional tillage (CT) and no-tillage (NT) in a very clayey Rhodic Hapludox in Southern Brazil. As a result of 19 years of no soil disturbance, soil chemical attributes related to soil acidity and the availability of $\mathrm{P}$ and $\mathrm{K}$ were more favorable to crops growth up to $10 \mathrm{~cm}$ in the soil under no-tillage than in the conventional tillage. On other hand, lime applications in low doses on the soil surface were not efficient in neutralizing the aluminum toxicity below $10 \mathrm{~cm}$ depth. It shows that repeated use of lime on the soil surface under NT system can be a viable alternative strategy only when soil acidity and aluminum toxicity in subsurface has been previously eliminated using the adequate amount of lime and incorporating it into the arable layer. Moreover, in the conventional tillage system $\mathrm{P}$ and K availability were higher below $10 \mathrm{~cm}$ depth compared to the no-tillage system. Even after 19 years of no soil disturbance in the NT system the available P content below $10 \mathrm{~cm}$ soil layer was lower than the optimal content of available P recommended to cash crops. The reduced surface K application over time was sufficient to gain adequate crop yields and to maintain the optimal content of soil available K in both soil management systems. The effects of soil management systems were predominant on the soil acidity attributes, and no effects of winter cover crops were observed on soil acidity attributes. Black oat and blue lupine were more efficient in P cycling, increasing the soil available P content especially in the surface soil under NT. The lower amount of biomass produced over time when no cover crops were used in the winter period resulted in lower $\mathrm{P}$ and $\mathrm{K}$ availability in the soil, showing the important role of growing winter species to maintain soil fertility.
\end{abstract}

\section{Introduction}

Most cultivated Oxisols in tropical and subtropical regions of the world have low soil organic carbon content and show nutrient depletion over time (Calegari and Alexander, 1998). In these

\footnotetext{
* Corresponding author. Tel.: +55 55 32208108; fax: +55 5532208256 .

E-mail addresses: danilo@ccr.ufsm.br, danilonesaf@gmail.com (D.R. dos Santos).
}

cultivated soils, the inputs of organic and inorganic fertilizers affect plant growth and nutrient recycling through crop residues, affecting also soil organic carbon dynamics (Craswell and Lefroy, 2001 ). Therefore, patterns of organic carbon decline and nutrient depletion in Oxisols that have been under long term cultivation are of great concern for sustainable crop production on these soils.

In tropical and subtropical regions there is demand for increasing production which is usually achieved by expanding the cultivation area to the marginal lands (Greenland et al., 1997). 
This is particularly critical especially where the average crop yields are declining in conventional production systems. To reverse it, the use of mineral fertilizers and lime can maintain the yields in areas with high production potential and increase the production on marginal areas. However, the growing demand for fertilizers and lime can make these practices economically nonviable over time (Craswell and Lefroy, 2001). Therefore, strategies to maintain or increase crop productivity, reducing the demand for fertilizers and lime must to be developed. Thus, the use of plant species more efficient in soil nutrients use and tillage systems that provide accumulation of nutrients in labile forms, are basic prerequisites to sustainable crop production systems.

The dynamics of essential nutrients and toxic elements are modified by the no-tillage (NT) system when compared to the conventional tillage (CT) system (Houx et al., 2011). Generally, fertilizers are applied on the soil surface layer, with the possibility to broadcast in the NT. In the NT system the soil is not disturbed and the nutrients retention capacity reaches slowly to saturation. It occurs because nutrients such as phosphorus, potassium, calcium, magnesium, all cation micronutrients and heavy metals, are strongly adsorbed to the soil colloids functional groups at the site of application in tropical and subtropical Oxisols. Moreover, in the NT system, crops residues are deposited on soil surface, maximizing the biocycling and bringing nutrients from the deeper to the upper soil layers. Therefore, several studies have shown that NT system builds up a nutrient availability gradient quickly, with higher concentration on the soil surface layers, mainly when the fertilizers applied are superior to the nutrients output from the system (Rheinheimer and Anghinoni, 2001, 2003). However, when nutrients deficiencies and aluminum toxicity have not been corrected before NT system implementation, it can promote root nutrients deficiency in the deeper soil layers and excess accumulation on the upper soil layers, which can be a limiting factor to the subsequent crop yields and also contribute to more nutrients losses by runoff (Panuelas et al., 2009).

The cultivation of different plant species can also change the dynamics of nutrients in the soil, especially the P dynamics (Horst et al., 2001; Tiecher et al., 2012a,b). Plant strategies that increase the soil-root contact are particularly important in the uptake of $\mathrm{P}$ which has very low mobility in Oxisols. In this context, Vu et al. (2010) observed that wheat (Triticum aestivum L.) absorbed greater amount of soil available phosphorus due to its root system that explored large volumes of soil. Furthermore, Wang et al. (2008) reported that the acquisition of phosphate in low availability conditions was improved by the release of protons by wheat. Li et al. (2008) showed that common bean decreased the rhizosphere $\mathrm{pH}$ by 1.66 units reducing also the available P-resin to $43 \%$ of the no-plant control soil. Many factors contribute to this $\mathrm{pH}$ change, including the imbalance in cation-anion uptake, particularly affected by nitrogen sources, and increased efflux of protons as a result of P deficiency (Gahoonia and Nielsen, 2004). Besides this, the exudation of organic acids like citrate, malate, fumarate etc., can promote the P mobilization by ligand exchange and by occupying or dissolution of P adsorption sites (Bayon et al., 2006). Neumann and Römheld (1999) found that metabolic changes related to exudation of carboxylic acids and protons by plant roots are induced due to P deficiency which depend on multiple factors, i.e. patterns of cation uptake and ability of plants to accumulate carboxylic acids in root tissue. The acquisition of $P$ of low lability due to exudation of organic acids has been observed in lupin (Lupinus albus L.) by several researchers (Bais, 2006; Bayon et al., 2006; Shane et al., 2008; Wang et al., 2008). Therefore, based on the above results, it can be expected that cultivating crops with different strategies to access soil nutrients over time may alter soil nutrients and acidity attributes, especially under NT system.
The objectives of this study include determining the long term effect of cultivation with different winter plant species under CT and NT system on: (i) vertical distribution of soil nutrient and (ii) the soil acidity distribution in soil profile to assess the sustainability of crop production.

\section{Materials and methods}

\subsection{Site description}

A long-term experiment was established in 1986 at the Agronomic Institute of Paraná) (IAPAR) experimental station at Pato Branco, Southwestern Paraná State, Brazil $\left(52^{\circ} 41^{\prime} \mathrm{W}, 26^{\circ} 07^{\prime} \mathrm{S}\right.$ and $700 \mathrm{~m}$ altitude) (Fig. 1). The soil of the experimental site is a very clayey Rhodic Hapludox (Latossolo Vermelho Aluminoférrico - Brazilian Soil Classification System) and very acid. The A horizon $(0-1 \mathrm{~m})$ has $72 \%$ clay, $14 \%$ silt, and $14 \%$ sand. The mineralogical composition of A horizon is $68 \%$ silicate type $1: 1$ (kaolinite and halloysite), $13 \%$ silicate type 2:1 (vermiculite and/or montmorillonite), $14 \%$ iron oxides and $5 \%$ gibbsite, and the iron oxides composition is $51 \%$ hematite, $36 \%$ goethite and $13 \%$ maghemite (Costa, 1996). The area belongs to the sub-humid tropical zone or Köeppen's Cfb (climate without dry season, with rainy summer and the average hottest month lower than $22{ }^{\circ} \mathrm{C}$ ). The annual rainfall (from 1979 to 2005) ranges from 1200 to $1500 \mathrm{~mm}$. The monthly average temperature and monthly average precipitation of the experimental station in the period 1979-2005 are presented in Fig. 2.

\subsection{History and layout of the experimental area}

The experimental area was covered by subtropical forest until 1976, then it was cleared and cultivated with maize (Zea mays L.), soybean (Glycine max Merrill) and beans (Phaseolus vulgaris L.) for 10 years in a conventional system ( 1 disc plow +2 disc harrowing). From 1976 to 1986, there were high soil losses by erosion, the crops residues were burned after each cultivation to facilitate soil management, and lime was applied several times at unknown rates. From the winter 1986, experimental treatments combining different soil tillage system and winter cover crop treatments were implanted in the experimental area in three blocks. Selected soil chemical attributes at the beginning of the experiment are presented in Table 1.

The winter treatment plots $(12 \mathrm{~m} \times 20 \mathrm{~m}$ ) were randomized in each block. After that each block was subdivided in two strips and was laid out into two soil management systems $(6 \mathrm{~m} \times 20 \mathrm{~m})$ within each winter treatments plot. Tillage treatments were conventional tillage (CT - one disc plow and two disc harrowing) and continuous no-tillage (NT). Several winter cover crop species were compared at various times throughout the 19-year period. The winter cover crops that were compared included: blue lupin (Lupinus angustifolius L.), hairy vetch (Vicia villosa Roth), black oat (Avena strigosa Schreb.), oilseed radish (Raphanus sativus L.), spring wheat ( $T$. aestivum L.), and fallow. These winter cover crop treatments were applied to main plots in the years 1986-1990, 1992, 1994, 1999-2001 and 2005. During the winter seasons of 1991, 1995, 1996 and 1998, the entire experimental area was planted with black oat; in 1993 the soil remained fallow in winter; and, in 1997, 2002, 2003 and 2004 black oat + radish were planted in all main plots. The cover crops (lupine, hairy vetch, oats and radish) were controlled at the flowering stage by cutting with a roller knife. Herbicide was applied to the weedy fallow treatment to kill vegetation. Some years after cutting with roller knife, the plots were sprayed with herbicide when control treatment using roller-cutter was incomplete. Wheat was harvested for grain until 1995 ( 7 crops) and straw was left on top of the soil as mulch or 


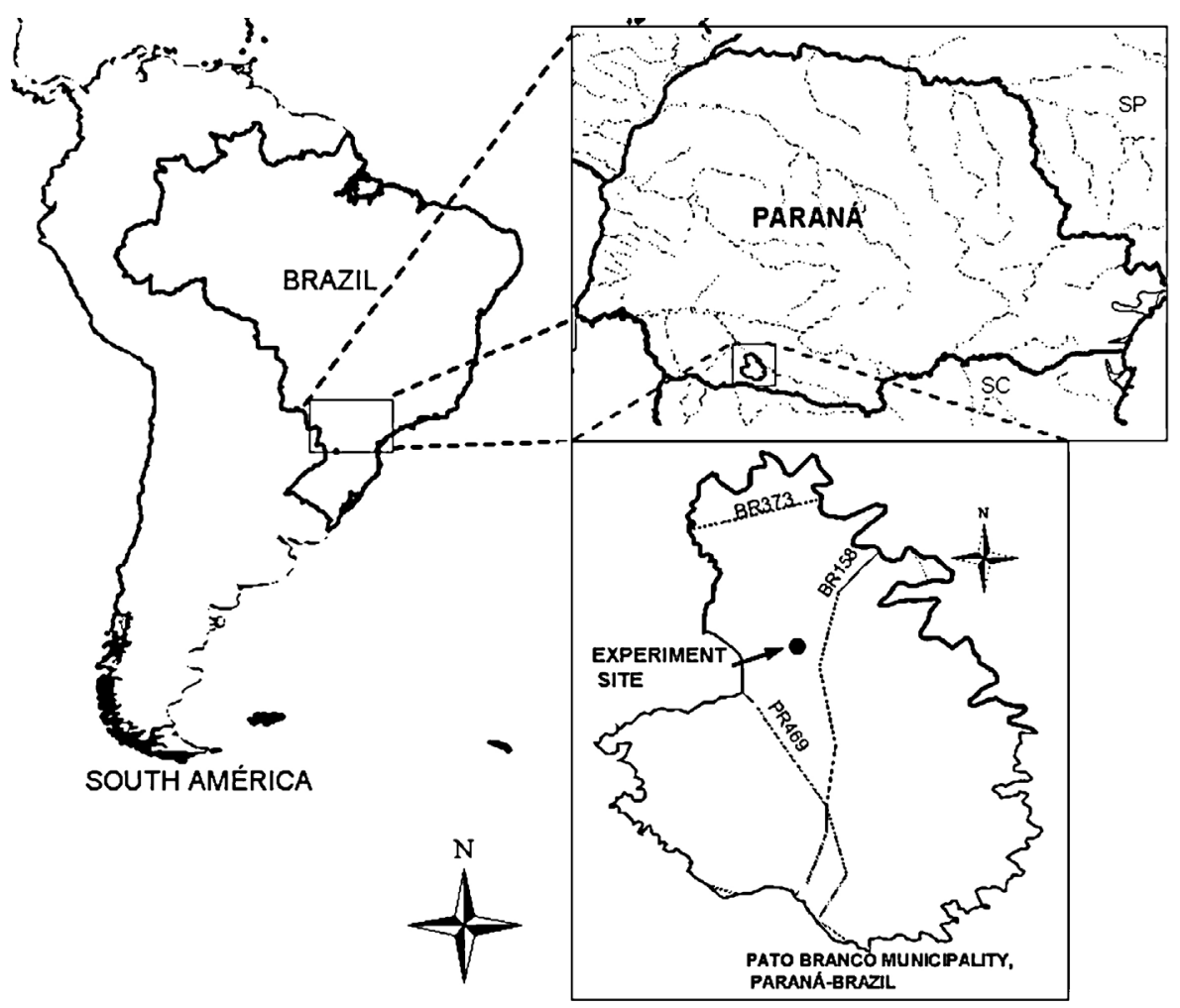

Fig. 1. Map of South America, Brazil, and Paraná State showing location of study site.

incorporated before planting the summer crop. Summer crops of maize and soybean were planted following the winter species. During the period of 1986-2005, maize was the summer crop for 8 years (1986-1988, 1992, 1994, 1996, 1999 and 2003) and soybean was the summer crop for 12 years (1989-1991, 1993, 1995, 1997, 1998, 2000-2005). The winter cover crops biomass yield, the summer crops residues and total above-ground dry biomass yield over 19 years under different winter treatments and soil managements systems are shown in Table 2.

Only the summer crops received fertilizer each year; the total amount of fertilizer applied during 19 years was $568 \mathrm{~kg} \mathrm{P} \mathrm{ha}^{-1}$, $618 \mathrm{~kg} \mathrm{Kha}^{-1}$, and $501 \mathrm{~kg} \mathrm{Nha}^{-1}$ using urea $\left.\left([\mathrm{NH}]_{2}\right)_{2} \mathrm{CO}\right)$ as a nitrogen source. All the winter crops were sown without fertilizers. Full $\mathrm{P}, \mathrm{K}$ and one-third of the $\mathrm{N}$ fertilizer were applied at planting time, while remaining two-thirds of the $\mathrm{N}$ was applied 45 days after planting. Lime was applied five times for a total of 9.5 $\mathrm{Mg} \mathrm{ha}^{-1}$ (1.0, 2.0, 3.0, 1.5 and $2.0 \mathrm{Mg} \mathrm{ha}^{-1}$ of lime (dolomite) in all plots, in 1989, 1992, 1995, 1999 and 2001, respectively). For

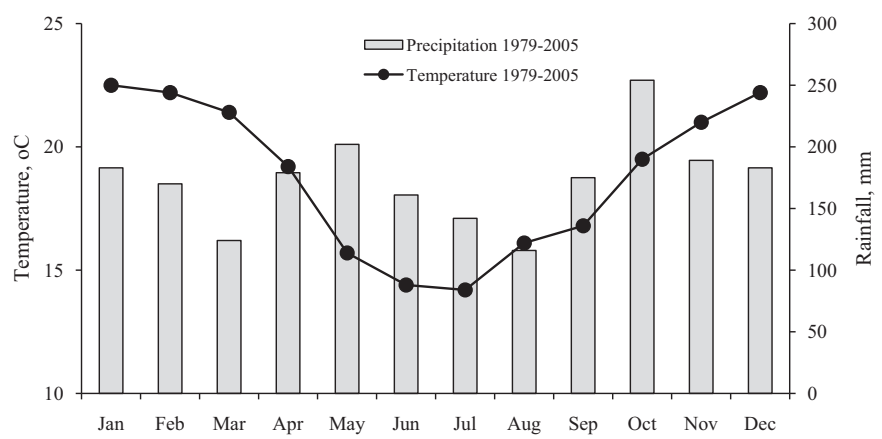

Fig. 2. Average temperature and precipitation in the experimental area in the period of 1979-2005.

Source: Meteorological Station of Experimental Station of IAPAR, Pato Branco, Paraná State. the NT system, lime was broadcasted on the soil surface and in the CT it was applied on the surface and then incorporated by plowing.

\subsection{Soil sampling and analyses}

Bulk soil samples were collected in October 2005, before the winter species management with roller knife at the flowering stage, taking care to avoid addition of crop residues and live plant material to the soil sample. A trench was opened in each plot and two subsamples of soil taken at six depths: 0-5, 5-10, 10-20, 20$30,30-40$ and $40-60 \mathrm{~cm}$. The soil sample from three trenches of the adjacent undisturbed forest that lies on the border of the experiment was also taken as control for comparison. All soil samples were air dried, sieved through $2 \mathrm{~mm}$ mesh and stored for further analysis.

Soil $\mathrm{pH}$ was determined in $0.01 \mathrm{M} \mathrm{CaCl}_{2}$ suspension $(1: 2.5$ soil:solution) after shaking for $20 \mathrm{~min}$; exchangeable $\mathrm{Al}^{3+}, \mathrm{Ca}^{2+}$, and $\mathrm{Mg}^{2+}$ were extracted by $1.0 \mathrm{M} \mathrm{KCl}$ (soil:extractant $1: 10$ ) for 20 min shaking. Exchangeable $\mathrm{Al}^{3+}$ was determined by titration with standardized $0.015 \mathrm{M} \mathrm{NaOH}$ solution using bromothymol blue indicator and $\mathrm{Ca}$ and $\mathrm{Mg}$ by atomic absorption spectroscopy. Available $\mathrm{P}$ and $\mathrm{K}$ were extracted by Mehlich-1 (soil:extractant $1: 10$ ), and then $\mathrm{K}$ was measured by flame photometer and $\mathrm{P}$ was colorimetrically determined by Murphy and Riley (1962) method. The potential acidity $\left(\mathrm{H}^{+}+\mathrm{Al}^{3+}\right)$ was calculated using Eq. (1) proposed by Kaminski et al. (2001) and adopted by CQFS-RS/SC (2004):

$\mathrm{H}^{+}+\mathrm{Al}^{3+}=\frac{e^{10.665-1.148 * \mathrm{pH} \mathrm{SMP}}}{10}$

where the $\mathrm{H}^{+}+\mathrm{Al}^{3+}$ is estimated by the $\mathrm{pH}$ balance of the soil with $1.78 \mathrm{M}$ SMP solution (triethanolamine, paranitrofenol, $\mathrm{K}_{2} \mathrm{CrO}_{4}$, $\mathrm{Ca}\left(\mathrm{CH}_{3} \mathrm{COO}\right)_{2}$ and $\mathrm{CaCl}_{2} \cdot 2 \mathrm{H}_{2} \mathrm{O}$ ) buffered at pH 7.5 (Shoemaker et al., 1961). The cation exchange capacity at $\mathrm{pH} 7.0\left(\mathrm{CEC}_{\mathrm{pH}}\right.$ 7.0) was calculated as the sum of $\mathrm{H}^{+}+\mathrm{Al}^{3+}+\mathrm{Ca}^{2+}+\mathrm{Mg}^{2+}+\mathrm{K}^{+}$(CQFS-RS/SC, 2004). 
Table 1

Selected soil chemical characteristics in the soil before the beginning of the experiment in 1986, affected by 10 years of cultivation under conventional tillage.

\begin{tabular}{|c|c|c|c|c|c|c|c|c|c|c|c|}
\hline \multirow[t]{2}{*}{ Soil depth $(\mathrm{cm})$} & \multirow[t]{2}{*}{$\operatorname{TOC}^{\mathrm{a}}(\%)$} & \multirow[t]{2}{*}{ Soil pH } & \multicolumn{3}{|c|}{$\begin{array}{l}\text { Exchangeable by } \\
1.0 \mathrm{M} \mathrm{KCl} \\
\left(\mathrm{cmol}_{\mathrm{c}} \mathrm{kg}^{-1}\right)\end{array}$} & \multirow[t]{2}{*}{$\mathrm{H}+\mathrm{Al}\left(\mathrm{cmol}_{\mathrm{c}} \mathrm{kg}^{-1}\right)$} & \multirow[t]{2}{*}{$\mathrm{CEC}_{\mathrm{pH} 7.0}\left(\mathrm{cmol}_{\mathrm{c}} \mathrm{kg}^{-1}\right)$} & \multirow[t]{2}{*}{$\mathrm{m}^{\mathrm{b}}(\%)$} & \multirow[t]{2}{*}{$\mathrm{V}^{\mathrm{c}}(\%)$} & \multicolumn{2}{|c|}{ Available by Mehlich I } \\
\hline & & & $\mathrm{Al}$ & $\mathrm{Ca}$ & $\mathrm{Mg}$ & & & & & $\mathrm{P}\left(\mathrm{mg} \mathrm{kg}^{-1}\right)$ & $\mathrm{K}\left(\mathrm{cmol}_{\mathrm{c}} \mathrm{kg}^{-1}\right)$ \\
\hline $0-10$ & 2.54 & 4.7 & 0.12 & 3.7 & 2.1 & 5.7 & 11.9 & 1.9 & 52 & 3.8 & 0.43 \\
\hline $10-20$ & 2.43 & 4.7 & 0.16 & 3.4 & 2.0 & 5.9 & 11.5 & 2.8 & 49 & 2.2 & 0.31 \\
\hline $20-40$ & 2.22 & 4.7 & 0.27 & 2.8 & 1.7 & 6.2 & 10.9 & 5.5 & 43 & 1.7 & 0.23 \\
\hline
\end{tabular}

\subsection{Statistical analyses}

For the analysis of variance (ANOVA) of the data, the following model was used:

$$
\begin{aligned}
Y_{i j k l}= & \mu+B_{i}+W_{j}+\text { error } a(i, j)+M_{k}+\text { error } b(i, k)+W M_{j k} \\
& + \text { error } c(i, j, k)+D_{l}+\text { error } d(i, l)+W D_{j l}+\text { error } e(i, j, l) \\
& +M D_{k l}+\text { error } f(i, k, l)+W M D_{j k l}+\text { error } g(i, j, k, l)
\end{aligned}
$$

where $\mu$ is the overall experimental average; $B$ is the blocks $(i=1$, $2,3) ; W$ is the winter treatment $(j=1,2,3,4,5,6) ; M$ is the soil management system $(k=1,2) ; D$ is the depth $(l=1,2,3,4,5,6)$ and 'error' represents the experimental error. The winter treatments were considered as a between-subject and the soil management systems and the soil layers were considered within-subjects. When treatment effects were significant at $5 \%$ probability of error by $F$ test, the differences between means of soil management systems were compared by the Least Significant Differences (LSD) test. Furthermore, in each soil layer, we compared the data from reference soil under forest $(n=3)$ with the cultivated soil under NT $(n=18)$ and the cultivated soil under CT $(n=18)$ using the MannWhitney $U$ test (non-parametric test).

\section{Results and discussion}

\subsection{Differences between cultivated and forest soil}

The natural forest presents typical characteristics of a highly weathered soil that occurs in subtropical regions. The soil $\mathrm{pH}$ in the

\section{Table 2}

\begin{tabular}{|c|c|c|c|c|c|c|c|c|}
\hline \multirow[t]{3}{*}{ Winter treatments } & \multicolumn{8}{|c|}{ Above-ground dry biomass yield $\left(\mathrm{Mg} \mathrm{ha}^{-1}\right)$} \\
\hline & \multicolumn{2}{|c|}{$\begin{array}{l}\text { Winter } \\
\text { cover } \\
\text { crops }^{\mathrm{a}}\end{array}$} & \multicolumn{2}{|c|}{$\begin{array}{l}\text { Summer } \\
\text { crops } \\
\text { residues }^{\text {b }}\end{array}$} & \multicolumn{2}{|l|}{ Total } & \multicolumn{2}{|c|}{$\begin{array}{l}\text { Annual } \\
\text { mean }\end{array}$} \\
\hline & NT & $\mathrm{CT}$ & NT & $\mathrm{CT}$ & NT & $\mathrm{CT}$ & NT & CT \\
\hline Fallow $^{\mathrm{c}}$ & 34.0 & 23.7 & 80.5 & 79.8 & 114.5 & 103.6 & 6.0 & 5.5 \\
\hline Wheat & 63.2 & 58.8 & 77.5 & 74.6 & 140.8 & 133.4 & 7.4 & 7.0 \\
\hline Vetch & 68.1 & 58.9 & 83.6 & 78.6 & 151.8 & 137.4 & 8.0 & 7.2 \\
\hline Radish & 71.3 & 58.0 & 85.4 & 84.5 & 156.7 & 142.4 & 8.2 & 7.5 \\
\hline Lupin & 69.6 & 60.9 & 82.8 & 78.1 & 152.4 & 139.0 & 8.0 & 7.3 \\
\hline Oat & 83.1 & 73.5 & 82.2 & 81.4 & 165.3 & 154.9 & 8.7 & 8.2 \\
\hline
\end{tabular}

Total above-ground dry biomass yield over 19 years in different winter treatments and soil management systems.

CT, conventional tillage; NT, no-tillage.

a Values are the sum of biomass yield of the winter cover crop used as treatments in 1986-1990, 1992, 1994, 1999-2001 and 2005; plus black oat biomass yield in 1991, 1995, 1996 and 1998; plus black oat + radish biomass yield in 1997, 20022004.

b Values are the sum of crops residues produced by maize cultivated in 1986$1988,1992,1994,1996,1999$ and 2003) and by soybean cultivated in 1989-1991 1993, 1995, 1997, 1998, 2000-2002 and 2004.

c The fallow biomass yield consisted of weed biomass. soil layer of $0-60 \mathrm{~cm}$ was 4 , and $\mathrm{Al}$ saturation increased from $53 \%$ to $89 \%$ in the soil layers of $0-5$ and $40-60 \mathrm{~cm}$, respectively (Table 3). The indigenous plants that occur in these high weathered soils are genetically and/or environmentally adapted to the soil acidity conditions provoked by Al. According to Vitorello et al. (2005), some plant mechanisms to survive under these adverse soil conditions are: (i) low plant growth synchronized to the low nutrients availability; (ii) increase of soil $\mathrm{pH}$ in the rizosphere soil; (iii) Al uptake and its subsequent complexation into the plants tissues; (iv) Al and Fe complexation by organic acids released by roots; ( $\mathrm{v}$ ) high $\mathrm{P}$ affinity; and (vi) micorryza associations. Additionally, the nutrients biocycling and the capability of organic compounds accumulated on the forest surface soil in complex toxic $\mathrm{Al}$ are also natural strategies that allow native plants to grow. The deforestation followed by burning of the native forest, contributes to obtain reasonable crop yields in the first 2-3 years. After that, nutrients depletion occurs and the crop cultivation that is not adapted to this environmental leads to lower crop yields. In Southern Brazil, this soil chemical depletion was responsible by the first farmer's migratory cycle that occurred before soil physical degradation (Mielniczuck et al., 2000).

When compared to the forest soil, the cultivated soil (mean of two soil management in the soil layer of $0-60 \mathrm{~cm}$ ) showed on average 0.8 units of $\mathrm{pH}$ increase and lowered the exchangeable $\mathrm{Al}$ content 12 times (Table 3 ). This change in soil acidity below cultivated surface layer occurred mainly because of continuous liming with continuous ploughing and disc harrowing operations from 1976 to 1986 before each crop growth season (Table 3). Thus, even under NT system modifications were observed in soil acidity attributes in the deeper soil layers (below $10 \mathrm{~cm}$ ) as a result of the early tillage and lime application.

The P availability in highly weathered soils under the forest soil is very low when the P demands by commercial crops are taken into account (Fig. 3a). However, the proportion of organic P in the surface soil of subtropical forests can be more than $50 \%$ of the soil total P (Rheinheimer and Anghinoni, 2003; Tiecher et al., 2012a), and the remaining $P$ is comprised of forms adsorbed to inorganic colloids with high bond energy and low bioavailability (Rheinheimer and Anghinoni, 2001). Therefore, in the forest soil, P availability depends largely on mineralization of organic P forms (Vincent et al., 2010).

After forest clearing, the amount of $P$ added during the first 10 years of cropping (from 1976 to 1986) was not enough to reach the critical level of $P$ availability, that is $6.0 \mathrm{mg} \mathrm{kg}^{-1}$ according to the CQFS-RS/SC (2004) (Fig. 3a). Large doses of phosphate fertilizers are needed in order to increase soil $P$ availability in soils with high adsorption capacity such as the Oxisols in this study. Note that these Oxisols have high clay content, are dominantly $1: 1$ clay minerals and have Fe oxides (Rheinheimer et al., 2003). This is confirmed by our results from CT system, where after 19 years, the $P$ availability still below the optimum levels for crop production and close to the content of available $P$ in the forest soil. 
Table 3

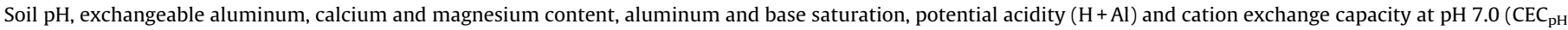
7.0), in the forest soil and in the cultivated soil affected by soil management after 19 years.

\begin{tabular}{|c|c|c|c|c|c|c|c|c|c|c|}
\hline \multirow[t]{2}{*}{ Soil depth $(\mathrm{cm})$} & \multicolumn{2}{|c|}{$\begin{array}{l}\text { Soil management } \\
\text { system }\end{array}$} & \multirow[t]{2}{*}{ Forest soil ${ }^{\ddagger}$} & \multicolumn{2}{|c|}{$P$-value ${ }^{\mathrm{a}}$} & \multicolumn{2}{|c|}{ Soil management system } & \multirow[t]{2}{*}{ Forest soil ${ }^{\ddagger}$} & \multicolumn{2}{|c|}{$P$-value ${ }^{\mathrm{a}}$} \\
\hline & NT & $\mathrm{CT}$ & & NT & $\mathrm{CT}$ & NT & $\mathrm{CT}$ & & NT & $\mathrm{CT}$ \\
\hline & \multicolumn{5}{|l|}{ Soil $\mathrm{pH}^{\dagger}$} & \multicolumn{5}{|c|}{ Exchangeable $\mathrm{Al}\left(\mathrm{cmol}_{\mathrm{c}} \mathrm{kg}^{-1}\right)^{\dagger}$} \\
\hline $0-5$ & $5.5 \mathrm{aA}$ & $4.8 \mathrm{bA}$ & 4.1 & 0.008 & 0.007 & $0.01 \mathrm{bD}$ & $0.12 \mathrm{aC}$ & 2.40 & 0.002 & 0.008 \\
\hline $5-10$ & $5.0 \mathrm{aB}$ & $4.8 \mathrm{bAB}$ & 4.0 & 0.008 & 0.008 & $0.15 \mathrm{aC}$ & $0.15 \mathrm{aBC}$ & 2.83 & 0.008 & 0.008 \\
\hline $10-20$ & $4.7 \mathrm{bC}$ & $4.8 \mathrm{aA}$ & 3.9 & 0.007 & 0.008 & $0.31 \mathrm{aB}$ & $0.15 \mathrm{bBC}$ & 2.95 & 0.008 & 0.008 \\
\hline $20-30$ & $4.5 \mathrm{bD}$ & $4.8 \mathrm{aAB}$ & 4.0 & 0.007 & 0.008 & $0.39 \mathrm{aA}$ & $0.16 \mathrm{bBC}$ & 2.74 & 0.008 & 0.008 \\
\hline $30-40$ & $4.5 \mathrm{bD}$ & $4.7 \mathrm{aB}$ & 4.0 & 0.007 & 0.008 & $0.41 \mathrm{aA}$ & $0.23 \mathrm{bA}$ & 2.51 & 0.008 & 0.008 \\
\hline \multirow[t]{2}{*}{$40-60$} & $4.6 \mathrm{bC}$ & $4.7 \mathrm{aB}$ & 4.1 & 0.007 & 0.008 & $0.29 \mathrm{aB}$ & $0.20 \mathrm{bAB}$ & 2.22 & 0.008 & 0.008 \\
\hline & \multicolumn{5}{|c|}{ Exchangeable $\mathrm{Ca}\left(\mathrm{cmol}_{\mathrm{c}} \mathrm{kg}^{-1}\right)^{\dagger}$} & \multicolumn{5}{|c|}{ Exchangeable $\mathrm{Mg}\left(\mathrm{cmol}_{\mathrm{c}} \mathrm{kg}^{-1}\right)^{\dagger}$} \\
\hline $0-5$ & $7.0 \mathrm{aA}$ & $3.8 \mathrm{bA}$ & 1.3 & 0.008 & 0.008 & $3.4 \mathrm{aA}$ & $2.3 \mathrm{bA}$ & 0.8 & 0.008 & 0.008 \\
\hline $5-10$ & $4.5 \mathrm{aB}$ & $3.9 \mathrm{bA}$ & 0.7 & 0.008 & 0.008 & $2.6 \mathrm{aB}$ & $2.2 \mathrm{bA}$ & 0.6 & 0.008 & 0.008 \\
\hline $10-20$ & $2.9 \mathrm{bC}$ & $3.8 \mathrm{aA}$ & 0.4 & 0.008 & 0.008 & $2.0 \mathrm{bC}$ & $2.2 \mathrm{aA}$ & 0.4 & 0.008 & 0.008 \\
\hline $20-30$ & $1.9 \mathrm{bD}$ & $3.0 \mathrm{aB}$ & 0.3 & 0.008 & 0.008 & $1.6 \mathrm{bD}$ & $2.0 \mathrm{aB}$ & 0.3 & 0.008 & 0.008 \\
\hline $30-40$ & $1.5 \mathrm{bE}$ & $2.0 \mathrm{aC}$ & 0.2 & 0.008 & 0.008 & $1.4 \mathrm{bE}$ & $1.6 \mathrm{aC}$ & 0.2 & 0.008 & 0.008 \\
\hline \multirow[t]{2}{*}{$40-60$} & $1.4 \mathrm{bE}$ & $1.6 \mathrm{aD}$ & 0.1 & 0.008 & 0.008 & $1.3 \mathrm{bE}$ & $1.5 \mathrm{aC}$ & 0.1 & 0.008 & 0.008 \\
\hline & \multicolumn{5}{|c|}{ Al saturation $(\%)^{\dagger}$} & \multicolumn{5}{|c|}{ Base saturation $(\%)^{\dagger}$} \\
\hline $0-5$ & $0.1 \mathrm{bE}$ & $2.2 \mathrm{aC}$ & 53.2 & 0.002 & 0.008 & $66 \mathrm{aA}$ & $46 \mathrm{bA}$ & 13 & 0.008 & 0.008 \\
\hline $5-10$ & $2.5 \mathrm{aD}$ & $2.7 \mathrm{aC}$ & 68.2 & 0.008 & 0.008 & $51 \mathrm{aB}$ & $45 \mathrm{bA}$ & 9 & 0.008 & 0.008 \\
\hline $10-20$ & $6.4 \mathrm{aC}$ & $2.9 \mathrm{bc}$ & 77.0 & 0.008 & 0.008 & $38 \mathrm{bC}$ & $45 \mathrm{aA}$ & 6 & 0.008 & 0.008 \\
\hline $20-30$ & $10.1 \mathrm{aB}$ & $4.1 \mathrm{bB}$ & 81.5 & 0.008 & 0.008 & $31 \mathrm{bD}$ & $41 \mathrm{aB}$ & 5 & 0.008 & 0.008 \\
\hline $30-40$ & $12.4 \mathrm{aA}$ & $6.8 \mathrm{bA}$ & 84.4 & 0.008 & 0.008 & $28 \mathrm{bE}$ & $34 \mathrm{aC}$ & 4 & 0.008 & 0.008 \\
\hline \multirow[t]{2}{*}{$40-60$} & $9.5 \mathrm{aB}$ & $6.1 \mathrm{bA}$ & 89.2 & 0.008 & 0.008 & $28 \mathrm{bE}$ & $32 \mathrm{aC}$ & 2 & 0.008 & 0.008 \\
\hline & \multicolumn{5}{|c|}{$\mathrm{H}+\mathrm{Al}\left(\mathrm{cmol}_{\mathrm{c}} \mathrm{kg}^{-1}\right)^{\dagger}$} & \multicolumn{5}{|c|}{$\mathrm{CEC}_{\mathrm{pH} 7.0}\left(\mathrm{cmol}_{\mathrm{c}} \mathrm{kg}^{-1}\right)^{\dagger}$} \\
\hline $0-5$ & $5.5 \mathrm{bC}$ & $7.5 \mathrm{aA}$ & 15.3 & 0.008 & 0.008 & $16.4 \mathrm{aA}$ & $14.0 \mathrm{bAB}$ & 17.5 & 0.175 & 0.008 \\
\hline $5-10$ & $7.3 \mathrm{bB}$ & $7.7 \mathrm{aA}$ & 14.3 & 0.008 & 0.008 & $14.7 \mathrm{aB}$ & $14.1 \mathrm{bA}$ & 15.6 & 0.248 & 0.145 \\
\hline $10-20$ & $8.3 \mathrm{aA}$ & $7.5 \mathrm{bA}$ & 13.9 & 0.008 & 0.008 & $13.5 \mathrm{aC}$ & $13.7 \mathrm{aB}$ & 14.8 & 0.119 & 0.079 \\
\hline $20-30$ & $8.2 \mathrm{aA}$ & $7.1 \mathrm{bB}$ & 13.1 & 0.007 & 0.008 & $11.8 \mathrm{aD}$ & $12.2 \mathrm{aC}$ & 13.7 & 0.039 & 0.079 \\
\hline $30-40$ & $7.9 \mathrm{aA}$ & $7.0 \mathrm{bB}$ & 12.0 & 0.008 & 0.008 & $11.0 \mathrm{aE}$ & $10.7 \mathrm{aD}$ & 12.4 & 0.079 & 0.008 \\
\hline $40-60$ & $7.3 \mathrm{aB}$ & $6.8 \mathrm{bB}$ & 11.7 & 0.008 & 0.008 & $10.1 \mathrm{aF}$ & $10.1 \mathrm{aE}$ & 12.0 & 0.039 & 0.014 \\
\hline
\end{tabular}

CT, conventional tillage; NT, no-tillage.

Values for each soil management system within each depth are the overall mean of six winter treatments ( $n=18$ ); means followed by the same letter in the row,

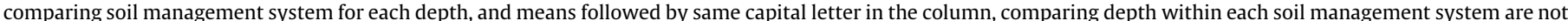
significantly different at $P<0.05$ by LSD test.

$¥$ Values for each depth in the forest soil are the mean of three samples $(n=3)$.

a Probability of difference between the forest soil and the cultivated soil under NT or CT by Mann-Whitney $U$ test.

In the forest soil, the available $\mathrm{K}$ content decreased from 0.18 to $0.05 \mathrm{cmol}_{\mathrm{c}} \mathrm{kg}^{-1}$ in the soil layers of $0-5$ and $40-$ $60 \mathrm{~cm}$, respectively (Fig. $3 \mathrm{~b}$ ). Indeed, the natural $\mathrm{K}$ availability in basaltic soils with high clay contents is relatively high in the soil surface and follows the distribution of negative charges in the soil profile. In the cultivated soil, the K availability after 19 years of cropping and fertilizer-K addition was higher than in the forest soil and also higher than the $K$ availability in the soil at the beginning of the experiment (Fig. 3b), showing that the amount of $\mathrm{K}$ applied over time was higher than the amount of $\mathrm{K}$ exported (crop grains and water erosion). a)

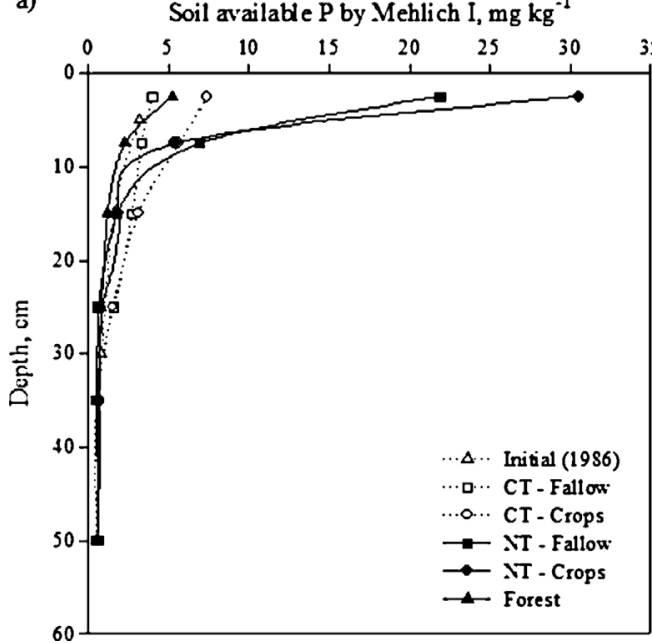

b) Soil avail able $\mathrm{K}$ by Mehlich I, $\mathrm{cmol}_{\mathrm{c}} \mathrm{kg}^{-1}$

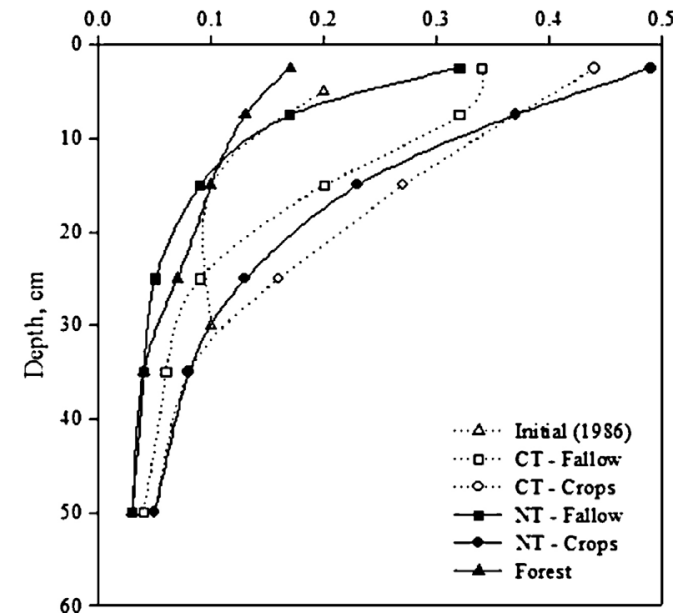

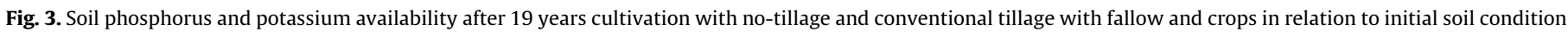
and forest soil. 
Table 4

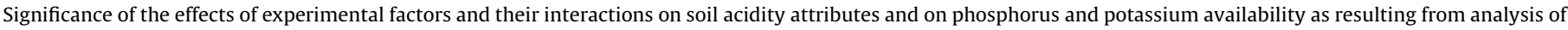
variance (ANOVA).

\begin{tabular}{|c|c|c|c|c|c|c|c|}
\hline Variable & Winter treatment $(W)$ & Soil management system $(M)$ & Depth $(D)$ & $W \times M$ & $D \times W$ & $D \times M$ & $D \times W \times M$ \\
\hline Soil pH & NS & NS & **** & NS & NS & *** & NS \\
\hline Exchangeable aluminum & NS & NS & ${ }^{* * *}$ & NS & NS & *** & NS \\
\hline Exchangeable calcium & NS & NS & $* * *$ & NS & NS & $* * *$ & NS \\
\hline Exchangeable magnesium & NS & NS & $* * *$ & NS & NS & ${ }^{* * *}$ & NS \\
\hline Potential acidity & NS & NS & $* * *$ & NS & NS & *** & NS \\
\hline $\mathrm{CEC}_{\mathrm{pH} 7.0}$ & NS & NS & $* * *$ & NS & NS & $* * * *$ & NS \\
\hline Base saturation & NS & NS & $* * *$ & NS & NS & *** & NS \\
\hline Aluminum saturation & NS & NS & ${ }^{* * *}$ & NS & NS & $* * *$ & NS \\
\hline Available potassium & NS & NS & $* * * *$ & ${ }_{* *}^{* *}$ & NS & $* * *$ & ${ }^{*}$ \\
\hline Available phosphorus & $* * *$ & & $* * *$ & ${ }^{*}$ & $* * *$ & $* * *$ & $* * *$ \\
\hline
\end{tabular}

NS, not significant.

* Significant at $P<0.05$.

** Significant at $P<0.01$.

Significant at $P<0.001$.

\subsection{Effect of tillage system and winter treatments on soil acidity attributes}

The soil $\mathrm{pH}$, exchangeable $\mathrm{Al}, \mathrm{Ca}$ and $\mathrm{Mg}$ content, $\mathrm{Al}$ and base saturation, potential acidity and $\mathrm{CEC}_{\mathrm{pH}}$ 7.0, were not affected by winter treatments, but showed significant interaction between soil management and soil depth (Table 4). This shows that the effects of soil management systems are preponderant on the soil acidity attributes compared to the cultivation of different cover crops. In fact, the effects of cultivation of different plants on soil acidity attributes are most frequently determined at rhizosphere level ( $\mathrm{Li}$ et al., 2008). As we did not evaluate the rhizosphere soil, but the bulk soil, it is possible that the winter cover crops effect on soil acidity attributes may have been diluted.

In comparison to the $\mathrm{CT}$, the soil layers up to $10 \mathrm{~cm}$ under NT showed increase in soil $\mathrm{pH}$, exchangeable $\mathrm{Ca}$ and $\mathrm{Mg}$ content, base saturation and $\mathrm{CEC}_{\mathrm{pH}}$ 7.0 whereas the potential acidity and $\mathrm{Al}$ saturation were decreased (Table 3 ). The exchangeable Al was lower in the NT system only in the soil layer of $0-5 \mathrm{~cm}$, and in the soil layer of $5-10 \mathrm{~cm}$ it was equal between the soil management systems. However, in the soil layer of $10-60 \mathrm{~cm}$, the soil $\mathrm{pH}$, exchangeable $\mathrm{Ca}$ and $\mathrm{Mg}$ content, and base saturation were lower under NT when compared to soil under CT. On the other hand, exchangeable $\mathrm{Al}$, potential acidity and $\mathrm{Al}$ saturation were higher in the soil layer of 10-60 cm under NT system when compared to the CT system.

After adopting the NT system, the total amount of lime applied on the soil surface was $9.5 \mathrm{Mg} \mathrm{ha}^{-1}$ over a 19 years period. As a consequence of this, there were lower active soil acidity and $\mathrm{Al}$ saturation, and higher exchangeable $\mathrm{Ca}$ and $\mathrm{Mg}$ content and base saturation (Table 3 ) in the soil layer of $0-10 \mathrm{~cm}$ under NT when compared to the soil under CT. These results were similar to the findings of Hargrove et al. (1982) and Edwards et al. (1992). Additionally, the nutrient recycling by crops under NT may contribute to the accumulation of $\mathrm{Ca}$ and $\mathrm{Mg}$ in the soil surface and the formation of availability gradient. However, the exchangeable Al was effectively neutralized in the $20-60 \mathrm{~cm}$ depth only in the CT system (Al saturation lower than 10\% - CQFS-RS/SC, 2004) (Table 3 ), due to the effect of slow migration of lime particles or their products to the deeper soil layers over time.

According to Rheinheimer et al. (2000a), high soil pH values result in decreased lime solubility. Thus, in the NT system the neutralization reaction of lime was limited to the upper layer, delaying the effect on subsurface layers and it is in accordance with the results of other researchers (Rheinheimer et al., 2000a, 2003; Kaminski et al., 2005; Caires et al., 1999; Kitur et al., 1994; Karlen et al., 1991; Ismail et al., 1994). To neutralize the acidity in subsurface layers the fine lime particles or the dissociation products must be moved down the soil profile (Rheinheimer et al., 2000a). Some factors that can contribute to lime migration in undisturbed soil profiles are: soil channels from crop roots continuous to the soil surface, water infiltration that can bring some lime particles into biopores (crop roots and fauna) and, earthworms and other soil organisms. However, in our experiment, the CT system was favorable to water infiltration and probably was the system where there was higher migration of small lime particles to the deeper soil layers (Calegari, 2006). Therefore, it is evident that lime application at lower rates to the soil surface is not efficient in neutralizing the aluminum toxicity in subsurface soil layers (below $10 \mathrm{~cm}$ depth) (Table 3 ). Consequently, repeated use of lime on the soil surface under NT system can be a viable alternative only when soil acidity and Al toxicity in subsurface has been previously corrected using the recommended site specific lime amount and incorporating it into the arable layer.

\subsection{Effect of tillage system and winter treatments on soil phosphorus and potassium availability}

The available P content showed significant interaction among soil management systems, winter treatments and depth. The maximum difference in available $\mathrm{P}$ content among the winter treatments were observed in the soil surface $(0-5 \mathrm{~cm})$ under NT system, where the highest average available $\mathrm{P}$ was obtained in the succession of cultures involving black oat $\left(45.8 \mathrm{mg} \mathrm{kg}^{-1}\right)$, followed by lupin (31.7 $\left.\mathrm{mg} \mathrm{kg}^{-1}\right)$, radish $\left(27.6 \mathrm{mg} \mathrm{kg}^{-1}\right)$, and vetch (26.7 $\left.\mathrm{mg} \mathrm{kg}^{-1}\right)$, and finally by wheat $\left(20.8 \mathrm{mg} \mathrm{kg}^{-1}\right)$ and fallow (21.9 $\mathrm{mg} \mathrm{kg}^{-1}$ ) (Table 5). The available $P$ in the $0-5 \mathrm{~cm}$ depth under CT system, the $5-10 \mathrm{~cm}$ and $10-20 \mathrm{~cm}$ depths in both soil management systems followed the same trends as the surface soil under NT system. However, the differences between the winter treatments were small. Bellow $20 \mathrm{~cm}$ depth, soil available P was smaller than $1.5 \mathrm{mg} \mathrm{kg}^{-1}$, showing no difference among winter treatments. The P uptake by plants from deeper layers accumulate on the surface after the decomposition of their residues (Rheinheimer and Anghinoni, 2001), promoting the higher difference in available P among the winter treatments in the soil layer of $0-5 \mathrm{~cm}$ under NT. However, in the CT the plowing distributed the organic waste in-depth, with the consequent reactions of $P$ with the soil after mineralization, decreasing the differences in the content of soil available P among the winter treatments.

Since there was no difference in yield and consequently in the amount of nutrients exported by corn and soybean grown during the 19 years of trial period, the lowest level of soil available $P$ in the fallow treatment was due to the 12 years when no crop was grown during winter. This resulted in a lower amount of biomass 
Table 5

Soil available phosphorus affected by soil management systems and winter treatments after 19 years.

\begin{tabular}{|c|c|c|c|c|c|c|c|}
\hline \multirow[t]{3}{*}{ Soil depth $(\mathrm{cm})$} & \multirow[t]{3}{*}{ Soil management system } & \multicolumn{6}{|c|}{ Soil available phosphorus $\left(\mathrm{mg} \mathrm{kg}^{-1}\right)$} \\
\hline & & \multicolumn{6}{|c|}{ Winter treatments ${ }^{\mathrm{a}}$} \\
\hline & & Fallow & Wheat & Vetch & Radish & Lupin & Oat \\
\hline \multirow[t]{2}{*}{$0-5$} & No-tillage & $21.9 \mathrm{dA}$ & $20.8 \mathrm{dA}$ & $26.7 \mathrm{cA}$ & $27.6 \mathrm{cA}$ & $31.7 \mathrm{bA}$ & $45.8 \mathrm{aA}$ \\
\hline & Conventional & $4.0 \mathrm{~dB}$ & $5.8 \mathrm{cB}$ & $6.4 \mathrm{cB}$ & $6.3 \mathrm{cB}$ & $8.8 \mathrm{bB}$ & $9.6 \mathrm{aB}$ \\
\hline \multirow[t]{2}{*}{$5-10$} & No-tillage & $6.9 \mathrm{bA}$ & $3.1 \mathrm{eB}$ & $5.0 \mathrm{cdB}$ & $4.7 \mathrm{~dB}$ & $5.5 \mathrm{cB}$ & $8.8 \mathrm{aA}$ \\
\hline & Conventional & $3.2 \mathrm{~dB}$ & $3.6 \mathrm{dA}$ & $6.2 \mathrm{bA}$ & $5.2 \mathrm{cA}$ & $7.1 \mathrm{aA}$ & $6.1 \mathrm{bB}$ \\
\hline \multirow[t]{2}{*}{$10-20$} & No-tillage & $1.8 \mathrm{bcB}$ & $1.4 \mathrm{bcB}$ & $1.2 \mathrm{cB}$ & $1.7 \mathrm{bcB}$ & $2.9 \mathrm{aB}$ & $2.0 \mathrm{bB}$ \\
\hline & Conventional & $2.7 \mathrm{bcA}$ & $3.4 \mathrm{abA}$ & $2.2 \mathrm{cA}$ & $2.8 \mathrm{bcA}$ & $3.9 \mathrm{aA}$ & $3.1 \mathrm{bA}$ \\
\hline
\end{tabular}

${ }^{\text {a }}$ LSD for depth $=0.67 \mathrm{mg} \mathrm{kg}^{-1}$.

production (Table 2) and consequently a lower amount of P cycled biologically. However, in the succession of cultures involving wheat, the lower content of available P probably was due to the $\mathrm{P}$ exported by seven wheat harvests between 1986 and 1995. In the succession of cultures involving black oat the amount of dry matter produced during the period of 1986-2005 was approximately $15 \mathrm{Mg} \mathrm{ha}^{-1}$ higher than in the other winter treatments (Table 2). Thus, these residues probably cycled a larger amount of $\mathrm{P}$, resulting in the higher content of soil available P, especially under NT system. Lupine is well known for excreting large amounts of organic acids such as citrate, malate and fumarate, even under relatively high $P$ availability (Bayon et al., 2006), which promotes the mobilization of P by ligand exchange and/or by dissolving and occupying the adsorption sites. Du to this higher excretion of organic acid, lupine possible accessed some soil $\mathrm{P}$ forms that are inaccessible to the other winter species. Thus, the lupine might cycle also large amounts of $\mathrm{P}$, which may have increased the concentration of soil available $P$.

For very clayey soils (clay content higher than 60\%) the recommendations of the CQFS-RS/SC (2004) in Southern Brazil, is that the optimum content of $\mathrm{P}$ available by Mehlich-I is between 6.0 and $12.0 \mathrm{mg} \mathrm{kg}^{-1}$. Below this range there is a high probability of crop response to $\mathrm{P}$ addition whereas the soil $\mathrm{P}$ levels higher than $24 \mathrm{mg} \mathrm{kg}^{-1}$ should be avoided to prevent P losses by runoff and aquatic environment disturbance. In this way, the available $P$ in the surface soil layer under NT reached critical environmental level, especially in the treatments involving oat and lupine. On the other hand, the content of available $P$ in the soil layer of $0-5 \mathrm{~cm}$ under CT system was within the recommendation level, although the soil available $P$ in the treatments involving fallow and wheat are below the critical level (Table 5).

In the surface soil layer $(0-5 \mathrm{~cm})$, the average amount of available P was 29.1 and $6.8 \mathrm{mg} \mathrm{kg}^{-1}$ in the NT and CT systems, respectively (Table 5). The higher amount of available $\mathrm{P}$ in the soil surface under NT compared to the soil under CT is a result of surface nutrient application and no soil disturbance in NT system, which avoids the exposure of new P adsorption labile sites (Tiecher et al., 2012b). Thus, in the NT system, the phosphate applied quickly saturates the inorganic soil adsorption sites (Rheinheimer et al., 2000b). Nevertheless, the nutrient availability was enhanced only in the surface soil layer $0-5 \mathrm{~cm}$. In the $10-20 \mathrm{~cm}$ depth, the available $\mathrm{P}$ content was higher in CT than in NT in all winter treatments. The soil layers below $10 \mathrm{~cm}$ depth in both soil managements (NT and CT) are below the critical level established by the CQFS-RS/SC (2004). Even the soil layer of $5-10 \mathrm{~cm}$ is $P$ deficient in many treatments (Table 5 ). This shows the difficulty to promote correction of $\mathrm{P}$ deficiency in subsurface layers after practicing the NT system, and that this deficiency should be corrected before starting the NT system.

Similar to $\mathrm{P}$, the available $\mathrm{K}$ content showed significant interaction among soil management systems, winter treatments and depth. There was no difference in soil available $\mathrm{K}$ among the winter cover crops. Nevertheless, compared to the treatments with cultivation of plants in the winter period, the fallow treatment showed lower content of available $\mathrm{K}$ in both soil management systems (Fig. 3b). It was also due to the 12 years in which there was no crop grown in winter period, which resulted in a lower amount of biomass produced (Table 2 ) resulting in a reduced $\mathrm{K}$ biocycling. Thus, these results demonstrate the important role of cultivation of winter species over time to maintain the levels of soil available K.

Unlike P, the enhancement of K availability in weathered soils is easily achieved, because this nutrient remains stored in soil cation exchange sites (Bortoluzzi et al., 2005). Generally, K adsorption in these soils is sufficiently strong to avoid the leaching process and sufficiently weak to supply the nutrient to the soil solution. According to the recommendation of the CQFS-RS/SC (2004) in Southern Brazil, the optimum content of available K by Mehlich-I is between 0.15 and $0.31 \mathrm{cmol}_{\mathrm{c}} \mathrm{kg}^{-1}$, and below this range there is a high probability of crop response to K addition. Thus, in both soil management systems (NT and CT) the available K levels in the soil layer of $0-10 \mathrm{~cm}$ are adequate to obtain reasonable crop yields in all winter treatments (Fig. 3b), showing that the applied doses ( $\approx 40 \mathrm{~kg} \mathrm{~K}_{2} \mathrm{O} \mathrm{ha}{ }^{-1}$ for each cash crop) was adequate to maintain high crop grain yields and enhance the K levels, as suggested by Brunetto et al. (2005) in the recommendation system of fertilizing in the states of Rio Grande do Sul and Santa Catarina.

\section{Conclusions}

As a result of 19 years of no soil disturbance, soil chemical attributes related to soil acidity and the availability of $\mathrm{P}$ and $\mathrm{K}$ were more favorable to crops growth up to $10 \mathrm{~cm}$ in the soil under NT than in the CT. On the other hand, lime applications in low doses on the soil surface were not efficient in neutralizing the aluminum toxicity below $10 \mathrm{~cm}$ depth, showing that repeated use of lime on the soil surface under NT system can be a viable alternative strategy only when soil acidity and aluminum toxicity in subsurface have been previously eliminated, using the adequate amount of lime and incorporating it into the arable layer. Moreover, in the CT system $\mathrm{P}$ and $\mathrm{K}$ availability were higher below $10 \mathrm{~cm}$ depth compared to the NT system. Even after 19 years of no soil disturbance in the NT system the available P content below $10 \mathrm{~cm}$ soil layer was lower than the optimal content of available $\mathrm{P}$ recommended for cash crops. The reduced surface $\mathrm{K}$ application over time was sufficient to gain adequate crop yields and to maintain the optimal content of soil available $\mathrm{K}$ in both soil management systems.

The effects of soil management systems were predominant on the soil acidity attributes, and no effects of winter cover crops were observed on soil acidity attributes. Black oat and blue lupine were more efficient in P cycling, increasing the soil available P content especially in the surface soil under NT. The lower amount of 
biomass produced over time when no cover crops were used in the winter period resulted in lower $\mathrm{P}$ and $\mathrm{K}$ availability in the soil, showing the important role of growing winter species to maintain soil fertility.

\section{References}

Bais, H.P., 2006. The role of Root exudates in rhizosphere interactions with plants and other organisms. Annual Review of Plant Biology 57, 233-266.

Bayon, R.C., Weisskopf, L., Martinoia, E., Jansa, J., Frossard, E., Keller, F., Föllmi, K.B. Gobat, J.-M., 2006. Soil phosphorus uptake by continuously cropped Lupinus albus: a new microcosm design. Plant and Soil 283, 309-321.

Bortoluzzi, E.C., Rheinheimer, D.S., Gatiboni, L.C., Kaminski, J., Tessier, D., 2005 Alterações na mineralogia de um Argissolo do Rio Grande do Sul afetado pela fertilização potássica. (Potassium fertilization affecting the mineralogy of a rhodic acrisol in Rio Grande do Sul - Brazil). Revista Brasileira de Ciência do Solo (Brazilian Journal of Soil Science) 29, 327-335.

Brunetto, G., Gatiboni, L.C., Rheinheimer, D.S., Saggin, A., Kaminski, J., 2005. Nível crítico e resposta das culturas ao potássio em um Argissolo sob sistema plantio direto.(Critical level and crop yield response to potassium in a typic Hapludalf under no-tillage). Revista Brasileira de Ciência do Solo (Brazilian Journal of Soil Science).29, 565-571.

Caires, E.F., Fonseca, A.F., Mendes, J., Chueiri, W.A., Madruga, E.F., 1999. Produção de milho, trigo e soja em função das alterações das características químicas do solo pela aplicação de calcário e gesso na superfície, em sistema de plantio direto.(Corn, wheat and soybean yields as a function of the changes in soil chemical characteristics due to surface application of lime and gypsum under a no-tillage system). Revista Brasileira de Ciência do Solo (Brazilian Journal of Soil Science).23, 315-327.

Calegari, A., 2006. Sequestro de carbono, atributos físicos e químicos em diferentes sistemas de manejo em um Latossolo argiloso do Sul do Brasil. (Carbon sequestration, physical and chemical properties in different managemen systems on a clayey Oxisol from Southern Brazil).Universidade Estadual de Londrina, Londrina, Paraná State, Brazil (PhD Diss. in agronomy).

Calegari, A. Alexander, I., 1998. The effect of tillage on some chemical properties of an Oxisol and summer crop yields in Southwestern Paraná. Advances in GeoEcology, Brazil 31, 1239-1246.

Comissão de Química e Fertilidade do Solo - CQFS-RS/SC, 2004. Manual de adubação e calagem para os estados do Rio Grande do Sul e Santa Catarina. (Liming and fertilizing manual for Rio Grande do Sul and Santa Catarina States).Núcleo Regional Sul da Sociedade Brasileira de Ciência do Solo, Porto Alegre.

Costa, A.C.S., 1996. Iron oxide mineralogy of soils derived from volcanic rocks in the Paraná River Basin, Brazil. The Ohio State University, Columbus (PhD Diss. in soil science).

Craswell, E.T., Lefroy, R.D.B., 2001. The role and function of organic matter in tropical soils. Nutrient Cycling in Agroecosystems 61, 7-18.

Edwards, H.H., Wood, C.W., Thurlow, D.L., Thurlow, D.L., Ruf, M.E., 1992. Tillage and crop rotation effects on fertility status of Hapludult soil. Soil Science Society of America Journal 56, 1577-1582.

Gahoonia, T.S., Nielsen, N.E., 2004. Root traits as tools for creating phosphorus efficient crop varieties. Plant and Soil 260, 47-57.

Greenland, D.J., Gregory, P.J., Nye, P.H., 1997. Land resources: on the edge of the Malthusian precipice: introduction and conclusions. Philosophical Transactions of the Royal Society of London, Series B 352, 861-867.

Hargrove, W.L., Reid, J.T., Touchton, J.T., Gallaher, R.N., 1982. Influence of tillage practices on the fertility status of an acid soil double-cropped soybean production. Agronomy Journal 74, 674-684.

Horst, W.J., Kamh, M., Jibrin, J.M., Chude, V.O., 2001. Agronomic measures for increasing $\mathrm{P}$ availability to crops. Plant Soil 237, 211-223.

Houx III, J.H., Wiebold, W.J., Fritschi, F.B., 2011. Long-term tillage and crop rotation determines the mineral nutrient distribution of some elements in a Vertic Epiaqualf. Soil and Tillage Research 122, 27-35.

Ismail, I., Blevins, R.L., Frye, W.W., 1994. Long term no tillage effects on soil properties and continuous corn yields. Soil Science Society of America Journal 58, 193-198.

Kaminski, J., Rheinheimer, D.S., Bartz, H.R., 2001. Proposta de nova equação para determinação do valor de $\mathrm{H}+\mathrm{Al}$ pelo uso do índice SMP em solos do RS e SC. (Proposal for a new equation for determining the value of $\mathrm{H}+\mathrm{Al}$ by the use of SMP index in soil of Rio Grande do Sul and Santa Catarina States). In: Proceedings: Annual Meeting of Official Network of Laboratories in the States of Rio Grande do Sul and Santa Catarina States, Frederico Westphalen, Rio Grande do Sul State, Brazil.
Kaminski, J., Rheinheimer, D.S., Gatiboni, L.C., Brunetto, G., Silva, L.S., 2005. Eficiência da calagem superficial e incorporada em um Argissolo sob sistema plantio direto.(Efficiency of superficial and incorporated liming on a Hapludalf prior to no-tillage implementation). Revista Brasileira de Ciência do Solo (Brazilian Journal of Soil Science).29, 573-580.

Karlen, D.L., Berry, E.C., Colvin, T.S., 1991. Twelve-year tillage and crop rotation effects on yields and soil chemical properties in Northeast Iowa. Communications in Soil Science and Plant Analysis 22, 1985-2003.

Kitur, B.K., Phillips, S.R., Olson, K.R., Ebelhar, S.A., 1994. Tillage effects on selected chemical properties of Grantsburg silt loam. Communications in Soil Science and Plant Analysis 25, 225-246.

Li, H., Shen, J., Zhang, F., Clairotte, M., Drevon, J.J., Le Cadre, E., Hinsinger, P., 2008 Dynamics of phosphorus fractions in the rhizosphere of common bean (Phaseolus vulgaris L.) and durum wheat (Triticum turgidum durum L.) grown in monocropping and intercropping systems. Plant and Soil 312, 139-150.

Mielniczuck, J., Rheinheimer, D.S., Vezani, F.M., 2000. Interações fertilidade e conservação do solo. (Fertility and soil conservation interactions). In: Proceedings: Annual Meeting of Brazilian Society of Soil Science, Santa Maria, Rio Grande do Sul State, Brazil.

Neumann, G., Römheld, V., 1999. Root excretion of carboxylic acids and protons in phosphorus-deficient plants. Plant and Soil 211, 121-130.

Panuelas, J., Sardans, J., Alcaniz, J.M., Poch, J.M., 2009. Increased eutrophication and nutrient imbalances in the agricultural soil of NE Catalonia. Spain Journal of Environment Biology 30, 841-846.

Rheinheimer, D.S., Anghinoni, I., 2001. Distribuição do fósforo inorgânico em sistemas de manejo de solo.(Distribution of inorganic phosphorus fraction in soil management systems). Pesquisa Agropecuária Brasileira (Brazilian Journal of Agricultural Research).36, 151-160.

Rheinheimer, D.S., Anghinoni, I., 2003. Accumulation of soil organic phosphorus by soil tillage and cropping systems in subtropical soils. Communications in Soil Science and Plant Analysis 34, 2339-2354.

Rheinheimer, D.S., Anghinoni, I., Conte, E., 2003. Sorção de fósforo em função do teor inicial e de sistemas de manejo de solos.(Phosphorus sorption in soil in relation to the initial content and soil management). Revista Brasileira de Ciência do Solo (Brazilian Journal of Soil Science).27, 41-49.

Rheinheimer, D.S., Santos, E.J.S., Kaminski, J., Bortoluzzi, E.C., Gatiboni, L.C., 2000a. Alterações de atributos do solo pela calagem superficial e incorporada a partir de pastagem natural.(Changes in acid soil properties by superficial and incorporated liming on natural pasture). Revista Brasileira de Ciência do Solo (Brazilian Journal of Soil Science).24, 797-805.

Rheinheimer, D.S., Anghinoni, I., Kaminski, J., 2000b. Depleção do fósforo inorgânico de diferentes frações provocada pela extração sucessiva com resina em diferentes solos e manejos.(Depletion of inorganic phosphorus fractions by successive extraction with resin in defferent soils and manegement systems). Revista Brasileira de Ciência do Solo (Brazilian Journal of Soil Science).24, 345-354.

Shane, M.W., Lambers, H., Cawthray, G.R., Kuhn, A.J., Schurr, U., 2008. Impact of phosphorus mineral source ( $\mathrm{Al}-\mathrm{P}$ or $\mathrm{Fe}-\mathrm{P})$ and $\mathrm{pH}$ on cluster-root formation and carboxylate exudation in Lupinus albus L. Plant and Soil 304, 169-178.

Shoemaker, H.E., Mclean, E.O., Pratt, P.F., 1961. Buffer methods for determining the lime requirement of soils with appreciable amounts of extractable aluminum. Proceedings - Soil Science Society of America 25, 274-277.

Tiecher, T., Rheinheimer, D.S., Calegari, A., 2012a. Soil organic forms under different soil management systems and winter crops, in a long term experiment. Soil and Tillage Research 124, 57-67.

Tiecher, T., Rheinheimer, D.S., Kaminski, J., Calegari, A., 2012b. Forms of inorganic phosphorus in soil under different long term soil tillage systems and winter crops. Revista Brasileira de Ciência do Solo (Brazilian Journal of Soil Science).36, 271-281.

Wang, X., Tang, C., Guppy, C.N., Sale, P.W.G., 2008. Phosphorus acquisition characteristics of cotton (Gossypium hirsutum L.), wheat (Triticum aestivum L.) and white lupin (Lupinus albus L.) under P deficient conditions. Plant and Soil 312 117-128.

Vincent, A.G., Turner, B.L., Tanner, E.V.J., 2010. Soil organic phosphorus dynamics following perturbation of litter cycling in a tropical moist forest. European Journal of Soil Science 61, 48-57.

Vitorello, V.A., Capaldi, F.R., Stefanuto, V.A., 2005. Recent advances in aluminum toxicity and resistance in higher plants. Brazilian Journal of Plant Physiology 17 , 129-143.

Vu, D.T., Tang, C., Armstrong, R.D., 2010. Transformations and availability of phosphorus in three contrasting soil types from native and farming systems: a study using fractionation and isotopic labeling techniques. Journal of Soils and Sediments $10,18-29$. 